\title{
EFFECT OF INJECTION WITH BEE VENOM EXTRACT ON PRODUCTIVE PERFORMANCE AND IMMUNE RESPONSE OF BROILER CHICKS
}

\author{
Ali, A. H. $H^{*}$ and K. M. Mohanny** \\ *Animal and poultry Production Department, Faculty of Agriculture, \\ South Valley University, Qena, Egypt \\ **Plant Protection Department, Faculty of Agriculture, South Valley \\ University, Qena, Egypt
}

\begin{abstract}
Ninety six unsexed one-day old; Ross 308 broiler chicks were randomly divided into 4 treatment groups. Each treatment had 3 replicates with 8 chicks each. The chicks of each replicate were allocated in a cage in a windowless house. The experimental period was divided into two feeding phases, starter (0-3 weeks of age) and grower (4-6 weeks of age). The basal experimental diets had 23.33 and $20.42 \%$ crude protein and 3115 and $3162 \mathrm{Kcal} \mathrm{ME} / \mathrm{kg}$ diet for the starter and the grower diet, respectively. Chicks in first treatment were injected muscularly with saline solution weekly and served as a control. Whereas, in treatments 2, 3 and 4 chicks were injected muscularly with $0.5,1.0$ and $1.5 \mathrm{mg}$ of honey bee venom (BV) extract weekly till 5 weeks of age, respectively.

Injection with $\mathrm{BV}$ decreased significantly $(\mathrm{P}<0.05)$ body weight $(\mathrm{BW})$ at 3 weeks of age, average daily gain (ADG) during the period from $0-3$ weeks of age and daily feed intake (FI) during the periods from 4-6 and 0-6 weeks of age. On the other hand, there were no significant differences $(P>0.05)$ in BW at 6 weeks of age, ADG at 4-6 and 0-6 weeks of age, FI during period from 0-3 weeks of age, feed conversion ratio, haemagglutinin antibody titers against (SRBC), aspartate amino transaminase (AST) and alanine amino transaminase (ALT), serum total protein, albumin (Alb.), globulin (Glb.), (Alb./Glb.), cholesterol and total lipids. These data indicate that injection of broiler with BV extract by these doses did not adversely affect the productive performance and physiological traits However,BV extract has the ability to enhance the immune responses of broiler chicks. But more research is needed in future to evaluate the best dose and different supplementation methods.
\end{abstract}

\section{INTRODUCTION}

There is a constant focus on animal welfare, care for the environment, and restricted use of medical drugs and production of a healthy product without chemical residues that endanger human health such as pesticides or medical drugs (Henrik and Petra, 2007 and Bolarinwa et al., 2013).

Antimicrobial use in the broiler farms is mainly for the improvement of meat production as a growth promoter. Suspension of some antimicrobial agents as growth promoters in animal feeds was followed by some regulatory authorities (Angulo et al., 2004 and Han et al., 2010). Bee venom (BV) contains more than forty pharmaceutically active substances, many of which are yet to be studied (Bolarinwa et al., 2013). Several studies have shown BV to exert both an anti-inflammatory effect, a property shared with nonsteroidal anti-inflammatory drugs (Jang et al.,2003), and an antibacterial 
effect involving no side effects in animal models (Han et al., 2006). Furthermore apitherapy using live honeybee stings had therapeutic value for pigs with respiratory diseases such as atrophic rhinitis, pleuropneumonia, and Glasser's disease (Choi et al., 2003). Bee venom (BV) supplementation via drinking water showed significant effects on overall performance of broilers during the early stage of life, so this makes BV treatment interesting as an alternative to antimicrobial growth promoter in broiler nutrition (Han et al., 2010). Bolarinwa et al., 2013 revealed that, the higher the level of BV administration through direct stinging resulted in the best immune status as indicated in some of the hematological response which is directly responsible for the immune status of the body.

Therefore this study was designed to evaluate the effects of intramuscularly injection with honey bee venom extract on the productive performance and some physiological responses of broiler chicks.

\section{MATERIALS AND METHODS}

This study was carried out at the Poultry Farm, Department of Animal and Poultry Production, Faculty of Agriculture, South Valley University, Qena. It was designed to evaluate the effects of injection with bee venom on the productive performance (body weight, daily gain, feed intake, feed conversion and mortality rate) and immune responses of broiler chicks.

\section{Chicks and Housing:}

Ninety six unsexed one-day old; Ross 308 broiler chicks were obtained from a commercial local source and used in this study. Chicks were randomly divided into 4 treatment groups. Each treatment had 3 replicates with 8 chicks each ( 4 treatments $X 3$ replicates $X 8$ chicks $=96$ chicks). Chicks in each replicate within each treatment had nearly similar initial live body weight. Chicks were reared in two-tiers wire floor battery in a windowless house. The chicks of each replicate were allocated in a cage with slatted floor of iron.

\section{Diets and management:}

The experimental period was divided into two feeding phases, starter (from 0-3 weeks of age) and grower (from 4-6 weeks of age). The basal experimental diets had 23.33 and $20.42 \%$ crude protein and 3115 and 3162 $\mathrm{Kcal} \mathrm{ME} / \mathrm{kg}$ diet for the starter and the grower diet, respectively (Table 1). Experimental diets were formulated to meet the nutrients requirements of the broiler chicks (NRC, 1998).

Chicks were full access to feed and water during the experimental period. Artificial light was applied to maintain 23 hrs light per day during the experimental period. The environmental temperature was about $32^{\circ} \mathrm{C}$ during the first week old and it was gradually reduced by about $2^{\circ} \mathrm{C}$ weekly until about $24^{\circ} \mathrm{C}$ at the fourth week up to the end of experiment (at 6 weeks of age).

The experiment was included four treatments; chicks in treatment 1 were injected muscularly with $0.5 \mathrm{ml}$ saline solution weekly and served as a control. Whereas, in treatments 2,3 and 4 chicks were injected muscularly 
with $0.5,1.0$ and 1.5 micron of bee venom weekly till 5 weeks of age, respectively. Venom were obtained from colonies of Apis mellifera carnica by the electric device unit of Mohanny (2005) and quickly packed in opaque glass vials and kept at $-5^{\circ} \mathrm{C}$ till use, then dissolved in distilled water with the mentioned concentrations just before use.

Table (1): Composition and calculated analysis of the starter and grower basal diets.

\begin{tabular}{|c|c|c|}
\hline Ingredients & Starter & Grower \\
\hline Yellow corn & 52.59 & 56.04 \\
Soybean meal (44\% CP) & 32.00 & 30.00 \\
Corn gluten (60\% CP) & 9.00 & 6.00 \\
Vegetable oil & 2.00 & 4.00 \\
Premix* & 0.30 & 0.30 \\
Dicalcium phosphate & 2.00 & 1.80 \\
Limestone & 1.00 & 1.00 \\
Lysine & 0.30 & 0.20 \\
Methionine & 0.25 & 0.125 \\
Choline chloride & 0.20 & 0.175 \\
Salt & 0.36 & 0.36 \\
Total & 100 & 100 \\
\hline \multicolumn{2}{|c|}{ Calculated values } & 20.42 \\
Crude protein \% & 23.33 & 3162 \\
Calcium \% $\%$ & 3115 & 0.86 \\
Av. Phosphorus \% & 0.91 & 0.43 \\
Methionine & 0.48 & 0.55 \\
Lysine \% & 0.74 & 1.27 \\
\hline
\end{tabular}

*Vitamins and minerals premix provided per kilogram of the diet: Vit A, 1000 IU; D3 2000 ICU; Vit E, 10 mg; Vit K, 1mg; B1, 10 mg; B2, 5 mg; B6, 1500 mg; B12, 10mg Pantothenic acid, $10 \mathrm{mg}$; Nicotinic acid, $30 \mathrm{mg}$; Folic acid, 1mg; Biotin, $50 \mathrm{mcg}$; Chloride, $500 \mathrm{mg}$; copper, $10 \mathrm{mg}$; iron, $50 \mathrm{mg}$; Manganese, $60 \mathrm{mg}$; Zinc, $50 \mathrm{mg}$, and selenium, $0.1 \mathrm{mg}$.

Hygiene:

Chicks were vaccinated against Newcastle disease three times, firstly with Hitchner B1 on the $7^{\text {th }}$ day of age and twice with Lasota strain in drinking water at 12 and 24 days of age. At 14 and 28 days of age, chicks were vaccinated against infectious bursal disease (Gumboro).

Productive performance:

Live body weight and feed intake were recorded at 0, 3 and 6 weeks of age for each replicate. Feed conversion ratio (gm feed: gm gain) was calculated for each replicate within each period. There was only one chick died at 42 days of age from the second treated group and one chick died at 42 days of age from the control group.

Physiological measurements:

\section{Blood sampling:}

Blood samples were collected from six chicks (chosen randomly) within each treatment at 5 and 6 weeks of age. Samples of about $3 \mathrm{ml}$ of blood were withdrawn from the brachial vein into collecting tube and allowed 
to clot at $5^{\circ} \mathrm{C}$ overnight, and then centrifuged at $3000 \mathrm{rpm}$ for 15 minutes. Blood serum was then obtained and stored at $-20^{\circ} \mathrm{C}$ until analysis.

Immunization and Titration:

At 5 weeks of age, five chicks from each treatment were injected intravenously in the brachial vein with $0.2 \mathrm{ml}$ of $10 \%$ suspension of packed sheep red blood cells (SRBC's). Sera were collected on the seventh day post immunization (at 6 weeks of age) and antibody titer against SRBC's was determined using the micro titer procedure described by Van der Zijpp and Leenstra (1980). Titers were expressed as the $\log _{2}$ of the reciprocal of highest dilution giving complete agglutination.

\section{Blood serum constituents:}

Obtained blood serum were subjected to determine: total protein and albumin as described by Kaplan and Szalbo, (1983) and Doumas, (1971), respectively, while serum globulin was obtained by subtracting the values of the albumin from the corresponding values of the total protein (albumin: globulin ratio was then calculated); total lipids (Schmit, 1964); cholesterol (Wiebe and Bernert, 1984); aspartate amino transaminase (AST) and alanine amino transaminase (ALT) were determined according to (Reitman and Frankel, 1975).

6. Statistical Analysis:

Data collected were statistically analyzed by the analysis of variance with the General Linear Model (GLM) procedure of the SAS Institute (SAS, 1996). All statements of significance are based on the 0.05 level of probability. Significant differences among treatments were performed using Duncan's multiple range test (Duncan, 1955).

\section{RESULTS AND DISCUSSION}

\section{Productive performance:}

Data of body weight at 21 and 42 days of age are listed in Table (2). Obtained data showed that all birds injected with BV extract were significantly $(P<0.05)$ lower in body weight at 21 days of age than those of the control group, although body weight in the second treated group was slightly lower than the control group. On the contrary, injection with BV extract had no significant effect on body weight at 42 days of age.

In the present study, data of daily body weight gain at (0-3), (4-6) and (0-6) weeks of age (Table, 2) indicates that injected groups with BV extract recorded lower $(\mathrm{P}<0.05)$ body gain during starter period of $0-3$ weeks of age, although body weight gain in the second treated group was slightly lower than the control group. On the other hand, broiler chicks injected with BV extract had no significant effect on daily gain from 4-6 and 0-6 weeks of age. These results are in partial agreement with Han et al. (2013) who revealed that no treatment-related clinical signs or body weight changes were observed in both guinea pigs and rats when administered with bee venom.

On the contrary, these results are in disagreement with the finding of Han et al. (2009 and 2010) who revealed that treatment of drinking water with BV resulted in significantly higher BW gain than in the control group $(P<$ 0.05 ). The average daily weight gain from $d 1$ to 28 was increased for birds 
supplemented with BV compared with control birds. The increase in BW gain was more pronounced with supplementation of $1 \mathrm{ppm}$ of BV compared with $0.5 \mathrm{ppm}$ of BV, although it was not significant. But both BV groups were significantly higher than the control group at $28 \mathrm{~d}$ of age $(P<0.05)$. On the other hand, Han et al. (2006) stated that stinging or subcutaneous injection of bee venom increased body weight of piglets insignificantly.

The reduction of body weight, body weight gain and feed intake may be related to intramuscularly injection by bee venom, whereas most researchers used bee venom in drinking water, oral, stinging by bees or subcutaneous injection, therefore the intramuscular injections may cause severe pain in the muscles as a result of toxic substances in bee venom (Phospholipase A which induces inflammation and strongest allergen and Melittin which higher doses cause inflammatory and haemolytic) causing a decrease in feed intake, which in turn caused a decrease in body weight, but the good influence of bee venom maximizes the benefit of consumed feed and therefore there were no significant differences in final body weight

Table (2): Averages \pm (SE) of body weight (gm) and daily body weight gain (gm) as affected by injection of bee venom.

\begin{tabular}{|c|c|c|c|c|c|}
\hline \multirow{2}{*}{ Items } & \multicolumn{2}{|c|}{ Body weight (gm) } & \multicolumn{3}{c|}{ Daily body weight gain (gm) } \\
\cline { 2 - 6 } Treat. & $\mathbf{2 1}$ days & $\mathbf{4 2}$ days & $\mathbf{0 - 3}$ weeks & $\mathbf{4 - 6}$ weeks & $\mathbf{0 - 6}$ weeks \\
\hline Control & $829.17 \pm 4.17^{\mathrm{a}}$ & $2233.63 \pm 116.88$ & $37.10 \pm 0.20^{\mathrm{a}}$ & $66.88 \pm 5.46$ & $51.99 \pm 2.78$ \\
0.5 & $783.33 \pm 11.02^{\mathrm{b}}$ & $2187.50 \pm 92.14$ & $34.92 \pm 0.52^{\mathrm{b}}$ & $66.87 \pm 3.91$ & $50.89 \pm 2.19$ \\
1.0 & $808.33 \pm 12.67^{\mathrm{ab}}$ & $2290.48 \pm 51.41$ & $36.11 \pm 0.60^{\mathrm{ab}}$ & $70.58 \pm 1.85$ & $53.34 \pm 1.22$ \\
1.5 & $785.42 \pm 5.51^{\mathrm{b}}$ & $2183.33 \pm 27.08$ & $35.02 \pm 0.26^{\mathrm{b}}$ & $66.57 \pm 1.04$ & $50.79 \pm 0.64$ \\
\hline
\end{tabular}

Means within each column bearing different letter(s) are significantly different $(\mathbf{P}<0.05)$

Data of feed intake at (0-3), (4-6) and (0-6) weeks of age are listed in Table (3). Obtained data explained that injection with bee venom affect significantly $(\mathrm{P}<0.05)$ on feed intake during $4-6$ and $0-6$ weeks of age being lower in all treated groups as compared with that of the control group. On the contrary, injection of broiler chicks with BV extract had no significant effect on feed intake at the starter period (0-3 weeks of age). These results are in disagreement with the finding of Han et al. (2009 and 2010) who revealed that treatment of drinking water with BV resulted in Feed intake was numerically higher, although not significantly higher, for birds supplemented with BV than control birds.

Obtained data in Table (3) explained that injection of broiler chicks with BV extract had no significant effect on feed conversion ratio during the all studied periods.

Table (3): Averages \pm (SE) of daily feed intake (gm) and feed conversion ratio as affected by injection of bee venom.

\begin{tabular}{|c|c|c|c|c|c|c|}
\hline \multirow{2}{*}{$\begin{array}{l}\text { Items } \\
\text { Treat. }\end{array}$} & \multicolumn{3}{|c|}{ Daily feed intake (gm) } & \multicolumn{3}{|c|}{ Feed conversion ratio } \\
\hline & $\begin{array}{c}0-3 \\
\text { weeks }\end{array}$ & $\begin{array}{c}4-6 \\
\text { weeks }\end{array}$ & $\begin{array}{c}0-6 \\
\text { weeks }\end{array}$ & $\begin{array}{c}0-3 \\
\text { weeks }\end{array}$ & $\begin{array}{c}4-6 \\
\text { Weeks }\end{array}$ & $\begin{array}{c}0-6 \\
\text { weeks }\end{array}$ \\
\hline Control & $58.90 \pm 0.84$ & $137.30 \pm 0.50^{a}$ & $98.10 \pm 0.56^{a}$ & $1.59 \pm 0.01$ & $2.08 \pm 0.19$ & $1.90 \pm 0.10$ \\
\hline 0.5 & $56.56 \pm 0.36$ & $129.66 \pm 2.08^{b}$ & $93.11 \pm 0.98^{b}$ & $1.62 \pm 0.03$ & $1.95 \pm 0.09$ & $1.83 \pm 0.06$ \\
\hline 1.0 & $57.11 \pm 1.00$ & $126.39 \pm 2.05^{b}$ & $91.75 \pm 0.79^{b}$ & $1.58 \pm 0.05$ & $1.79 \pm 0.02$ & $1.72 \pm 0.03$ \\
\hline 1.5 & $56.68 \pm 0.21$ & $121.23 \pm 0.77^{c}$ & $88.95 \pm 0.28^{c}$ & $1.62 \pm 0.01$ & $1.82 \pm 0.04$ & $1.75 \pm 0.03$ \\
\hline
\end{tabular}

Means within each column bearing different letter(s) are significantly different $(\mathrm{P}<0.05)$ 


\section{Physiological measurements:}

Data of serum total protein, albumin, globulin and albumin/globulin ratio at $5^{\text {th }}$ and $6^{\text {th }}$ week of age are listed in Table (4). Obtained data showed that injection of BV extract had insignificant effect on total protein, albumin, globulin and albumin/globulin ratio at $5^{\text {th }}$ and $6^{\text {th }}$ week of age. These results are in agreement with the finding of Han et al. (2006).

Han et al. (2010) observed that, there were no significant effects of BV supplementation were noticed on total protein, albumin, and globulin with BV supplementation via drinking water. Moreover, Elshater et al. (2014) stated that exposed whole body of rats to a single dose of gamma radiation, induced a highly significant $(p<0.01)$ increase in serum ALT and AST activities as compared with the corresponding normal values. It induced also a highly significant decrease at $(p<0.01)$ in serum Albumin level when compared with normal level. After oral administration of Bee venom treatments for 40 days, there were a significant decrease $(p<0.05)$ in serum ALT and AST activities when compared with control animals and there was a significant increase at $(p<0.05)$ in Albumin level as compared with control animals.

Table (4): Averages \pm (SE) of serum total protein, albumin, globulin and albumin/globulin ratio as affected by injection of bee venom.

\begin{tabular}{|c|c|c|c|c|c|c|c|c|}
\hline \multirow[b]{2}{*}{ Treat. } & \multicolumn{2}{|c|}{$\begin{array}{l}\text { Total protein } \\
\text { (g/ dl ) }\end{array}$} & \multicolumn{2}{|c|}{$\begin{array}{l}\text { Albumin } \\
\text { (g/dl ) }\end{array}$} & \multicolumn{2}{|c|}{$\begin{array}{l}\text { Globulin } \\
\text { (g/ dl ) }\end{array}$} & \multicolumn{2}{|c|}{ Alb./Glob. } \\
\hline & $\begin{array}{c}35 \\
\text { days }\end{array}$ & $\begin{array}{c}42 \\
\text { days }\end{array}$ & $\begin{array}{c}35 \\
\text { days }\end{array}$ & $\begin{array}{c}42 \\
\text { days }\end{array}$ & $\begin{array}{c}35 \\
\text { days }\end{array}$ & $\begin{array}{c}42 \\
\text { days }\end{array}$ & $\begin{array}{c}35 \\
\text { days }\end{array}$ & $\begin{array}{c}42 \\
\text { days }\end{array}$ \\
\hline \multirow[t]{2}{*}{ Control } & $5.71 \pm$ & $5.49 \pm$ & $3.22 \pm$ & $2.64 \pm$ & $2.49 \pm$ & $2.86 \pm$ & $1.30 \pm$ & $1.00 \pm$ \\
\hline & 0.14 & 0.57 & 0.22 & 0.13 & 0.10 & 0.58 & 0.14 & 0.18 \\
\hline \multirow[t]{2}{*}{0.5} & $4.98 \pm$ & $5.02 \pm$ & $2.71 \pm$ & $2.59 \pm$ & $2.27 \pm$ & $2.42 \pm$ & $1.23 \pm$ & $1.12 \pm$ \\
\hline & 0.27 & 0.30 & 0.06 & 0.11 & 0.29 & 0.35 & 0.16 & 0.16 \\
\hline \multirow[t]{2}{*}{1.0} & $5.60 \pm$ & $5.38 \pm$ & $2.89 \pm$ & $2.60 \pm$ & $2.71 \pm$ & $2.78 \pm$ & $1.11 \pm$ & $0.93 \pm$ \\
\hline & 0.24 & 0.08 & 0.13 & 0.10 & 0.34 & 0.03 & 0.18 & 0.04 \\
\hline \multirow[t]{2}{*}{1.5} & $5.14 \pm$ & $5.47 \pm$ & $2.92 \pm$ & $2.76 \pm$ & $2.22 \pm$ & $2.71 \pm$ & $1.31 \pm$ & $1.05 \pm$ \\
\hline & 0.34 & 0.38 & 0.23 & 0.04 & 0.12 & 0.36 & 0.05 & 0.14 \\
\hline
\end{tabular}

Data of serum cholesterol and total lipids at 5 and 6 weeks of age are listed in Table (5). Injection with BV extract had insignificant effect on cholesterol and total lipids levels at 5 and 6 weeks of age.

These results are in agreement with those outlined by Han et al. (2010) who stated that no significant effects of BV supplementation via drinking water were noticed on total cholesterol.

Mousavi et al 2012 revealed that bee venom decreased significantly elevated levels of triglyceride and total cholesterol in diabetic rats to the normal levels. 
Table (5): Averages \pm (SE) of serum cholesterol and total lipids as affected by injection of bee venom.

\begin{tabular}{|c|c|c|c|c|}
\hline \multirow{2}{*}{ Ireat. } & \multicolumn{2}{|c|}{$\begin{array}{l}\text { Cholesterol } \\
\text { (mg/ dl) }\end{array}$} & \multicolumn{2}{|c|}{ Total lipids (mg/ dl) } \\
\hline & 35 days & 42 days & 35 days & 42 days \\
\hline Control & $124.27 \pm 7.15$ & $116.79 \pm 10.34$ & $1037.26 \pm 6.82$ & $1070.69 \pm 21.18$ \\
\hline 0.5 & $124.15 \pm 14.83$ & $125.67 \pm 11.13$ & $1055.96 \pm 10.46$ & $1040.43 \pm 24.02$ \\
\hline 1.0 & $130.54 \pm 11.88$ & $124.81 \pm 7.25$ & $1050.53 \pm 5.03$ & $1085.76 \pm 22.26$ \\
\hline 1.5 & $117.12 \pm 5.92$ & $132.48 \pm 8.48$ & $1070.36 \pm 12.47$ & $1083.29 \pm 20.44$ \\
\hline
\end{tabular}

Data of serum aspartate aminotransferase (AST) and alanine aminotransferase (ALT) at 5 and 6 weeks of age are listed in Table (6). Obtained data illustrated that injection of BV extract had insignificant effect on AST and ALT at the 5th and 6th weeks of age. Han et al. (2010) observed that, there were no significant effects of BV supplementation were noticed on AST and ALT with BV supplementation via drinking water. Moreover, Bolarinwa et al., 2013 showed that, stinging with BV had no effects $(P>0.05)$ on the PCV, RBC, WBC platelets, AST and ALT levels between the control and the tested treatments

Darwish et al. (2013) found that concurrent treatment with BV had significantly decreased the methotrexate-induced elevation of serum tumor necrosis factor-alpha (TNF-a), ALT and AST levels to the normal levels, indicating the hepato-protective effect of $\mathrm{BV}$, which might be explained by the reduction of elevated nuclear factor kappa-B (NF-kB) expression in liver. These results are consistent with other studies that showed the potent hepato-protective effect of BV by inhibiting the secretion of pro-inflammatory cytokines, such as TNF-a, and decreasing the elevated serum aminotransferase enzymes in different models of induced hepatic injury, such as ethanol and actinomycin-D through the inhibition of deoxyribonucleic acid damage (Park et al. (2010) and Kim et al. (2010))

Grisotto et al 2006 revealed that there was a significant increase in serum lactic dehydrogenase (LDH),creatine phosphokinase (CPK) and AST in the venom group as compared to control animals (Lyophilized bee venom $0.5 \mathrm{mg} / \mathrm{kg}$, was diluted in saline and infused in the jugular vein at the rate of $0.05 \mathrm{ml} / \mathrm{min}$ and Control animals received the same volume of saline) whereas ALT and hematocrit (Hct) did not change significantly. On the contrary, Ivas et al. (2011) stinging rabbits with 3, 6 or 12 stings per animal (one sting is equivalent to $0.1 \mathrm{mg}$ of venom). The inoculation of bee venom as individual $0,3 \mathrm{mg}$ doses on the rabbits under study made evident the progressive increase in the serum level of transaminases (ALT and AST) and of urea which demonstrated the insidious and slow occurrence of the hepatotoxicity and renal dysfunction, with even low venom doses. 2. The inoculation of the bee venom as 0.6 and $1.2 \mathrm{mg}$ doses per rabbit revealed the quick increase after 2-6 $\mathrm{h}$ of the serum transaminases (AST and ALT) with a recovery after $24 \mathrm{~h}$. but also an increase in ALP $24 \mathrm{~h}$ after inoculation which is indicative of the occurrence of some reversible hepatocellular lesions (it is to be elucidated the ALP increase to originate in either colangiocellulare or corticusuprarenal lesions.) 
Table (6). Averages \pm (SE) of serum Aspartate aminotransferase AST and, Alanine aminotransferase ALT as affected by injection of bee venom.

\begin{tabular}{|l|c|c|c|c|}
\hline \multirow{2}{*}{ Treat. } & \multicolumn{2}{|l|}{ ALT (U/I) } & \multicolumn{1}{|c|}{ A \& ages $(\mathbf{U} / \mathbf{I})$} \\
\cline { 2 - 5 } & 35 days & 42 days & 35 days & 42 days \\
\hline Control & $72.71 \pm 6.98$ & $76.58 \pm 3.01$ & $19.68 \pm 6.95$ & $18.84 \pm 7.08$ \\
0.5 & $75.44 \pm 2.91$ & $76.84 \pm 3.57$ & $18.93 \pm 5.72$ & $18.63 \pm 6.64$ \\
1.0 & $71.40 \pm 2.17$ & $80.40 \pm 8.56$ & $18.19 \pm 4.23$ & $18.49 \pm 7.28$ \\
1.5 & $71.17 \pm 23.93$ & $81.08 \pm 11.85$ & $18.17 \pm 4.45$ & $19.83 \pm 2.86$ \\
\hline
\end{tabular}

Averages of serum haemagglutinin antibody (Ab.) titers at 6 weeks of age are listed in Table (7). Obtained data elucidated that, injection of broilers with BV extract did not show any significant effect on Ab. titers at 6 weeks of age. However, there were numerical increases in Antibody titer of chicks that injected with the higher doses of BV. These results are in agreement with the finding of Han et al. (2006).

Table (7): Averages $\pm(\mathrm{SE})$ of haemagglutinin antibody (Ab) titers against (SRBC's) as affected by injection of bee venom.

\begin{tabular}{|l|l|c|c|c|}
\hline & Control & $\mathbf{0 . 5}$ & $\mathbf{1 . 0}$ & $\mathbf{1 . 5}$ \\
\hline $\mathrm{Ab} .$. & $9.07 \pm 0.36$ & $9.81 \pm 0.57$ & $10.65 \pm 0.22$ & $10.44 \pm 0.31$ \\
\hline
\end{tabular}

It is concluded that honey BV injection to broiler chicks could bee used as a natural product for stimulating and improving the immune responses of broiler chicks without negative effects on productive performance and blood biochemical parameters. The route of administration and the best effective dose need further research .

\section{REFERENCES}

Angulo, F. J.; N. L. Baker; S. J. Olsen; A. Anderson and T. J. Barrett, (2004). Antimicrobial use in agriculture: Controlling the transfer of antimicrobial resistance to humans. Semin. Pediatr. Infect. Dis. 15:78-85.

Bolarinwa, M. O.; M. A. Popoola; T. I. ljaduola and A. E. Sodeeq,( 2013). Evaluation of the Effect of Bee venom Administration on the Serology and Haematology of Broiler Chicken. Inter. J. Appl. Sci. Engr., 1(1): 23-24.

Celik, L., O. Ozturkcan, T. C. Inal, N. Canacankatan, and L. Kayrin.( 2003). Effects of I-carnitine and niacin supplied by drinking water on fattening performance, carcass quality and plasma I-carnitine concentration of broiler chicks. Arch. Tierernahr. 57:127-136.

Choi, S. H., S. K. Cho, S. S. Kang, C. S. Bae, Y. H. Bai, S. H. Lee, and S. C. Pak. 2003. Effect of apitherapy in piglets with preweaning diarrhea. Am. J. Chin. Med. 31:321-326.

Darwish SF, El-Bakly WM, Arafa HM, El-Demerdash E (2013) Targeting TNF-a and NF-kB Activation by Bee Venom: Role in Suppressing Adjuvant Induced Arthritis and Methotrexate Hepatotoxicity in Rats. PLoS ONE 8(11): e79284. 
Doumas, B. T., 1971. Automated analysis. Bochringer Mannheim Clin. Acta. 31-87.

Duncan, D. B., (1955). Multiple ranges and multiple F-test. Biometric, 11: 1042.

Elshater, A. A. ; M. M., Mohi Eldin; M. M. A. Salman and N. R. A. Kasem, (2014). The curative effect of Bee Venom and Propolis on oxidative stress induced by $\mathrm{Y}$-irradiation on blood and tissues of rats. Egypt. Acad. J. Biolog. Sci., 6(1): $53-69$.

Grisotto L. S. D.; G. E. Mendesa; I. Castrob; M. A. S. F. Baptistaa; V. A. Alvesc; L. Yub and E. A. Burdmanna, 2006. Mechanisms of bee venom-induced acute renal failure. Toxicon 48 (2006) 44-54

Han S. M., K. G. Lee, J. H. Yeo, H.Y. Kweon, B. Y. Oh, Y.G. Lee, B. S. Kim , H. J. Baek and S. T. Kim, 2006. Effects of Honeybee (Apis Mellifera L.) Venom Injection on the Growth Performance and Hematological Characteristics in Pigs. Korean J Vet Serv (2006) 29(3): 287-295

Han, S. M., K. G. Lee, J. H. Yeo, S. J. Hwang, C. H. Jang, P. J. Chenoweth, and S. C. Pak. 2009. Effects of bee venom treatment on growth performance of young pigs. Am. J. Chin. Med. 37:253-260.

Han S. M., K. G. Lee , J. H. Yeo, B. Y. Oh, B. S. Kim , W. Lee, H. J. Baek, S. T. Kim, S. J. Hwang, and S. C. Pak, (2010). Effects of honeybee venom supplementation in drinking water on growth performance of broiler chickens. Poult. Sci. 89: 2396-2400.

Han, S. M.; K. G. Lee; K. K. Park and S. Cheon, 2013. Skin sensitization study of bee venom (Apis mellifera L.) in guinea pigs and rats. Cutaneous and Ocular Toxicology, 32(1): 27-30.

Henrik $\mathrm{H}$ and S Petra, 2007. Organic agriculture and Animal Health, Executive summary. Pg. 7. Published in Germany by IFOAM.

Ivas, C.; G. Solcan; G. Pavel; I. Burcă and R. Malancuş, 2011. Studies on modifications of the hepatic and renal biochemical parameters of rabbits after bee venom inoculation. Lucrări ştiinţifice, 56: 143-147.

Jang, M. H., M. C. Shin, S. Lim, S. M. Han, H. J. Park, I. Shin, J. S. Lee, K. A. Kim, E. H. Kim, and C. J. Kim. 2003. Bee venom induces apoptosis and inhibits expression of cyclooxygenase-2 mRNA in human lung cancer cell line NCl-H1299. J. Pharmacol. Sci. 91:95104.

Kaplan, A. and J. Szalbo, 1983. Clinical chemistry: interpretation and techniques. 2nd ed. P157.

Kim KH, Kum YS, Park YY, Park JH, Kim SJ, et al. (2010) The protective effect of bee venom against ethanol-induced hepatic injury via regulation of the mitochondria-related apoptotic pathway. Basic Clin Pharmacol Toxicol 107: 619-624.

Klasing, K. C., 1998. Nutritional modulation of resistance to infectious diseases. Poult. Sci. 77: 1119-1125.

Mohanny, K. M. (2005). Investigations on propolis and bee venom produced by two hybrids of honeybee with reference to a new device for bee venom collection. Ph.D. Thesis, Fac Agric. Fayoum, Cairo Univ. 
Mousavi, S. M. ; S. Imani; S. Haghighi; S. E. Mousavi and A. Karimi, (2012). Effect of Iranian Honey bee (Apis mellifera) Venom on Blood Glucose and Insulin in Diabetic Rats. J Arthropod Borne Dis. 6(2): 136-143.

National Research Council, NRC, (1998). Nutrient Requirements of Poultry, 10th ed. Washington, DC, National Academy Press.

Park JH, Kim KH, Kim SJ, Lee WR, Lee KG, et al. (2010) Bee venom protects hepatocytes from tumor necrosis factor-alpha and actinomycin D. Arch Pharm Res 33: 215-223.

Reitman, S. and S. Frankel, 1975. A calorimetric methods for determination of glutamic oxaloacetic and glutamic pyruvic transaminase. Am. J. Clin. Path. 28: 56-63.

SAS, (1996). SAS User's Guide, statistics (6.2th Ed.) Cary NC: SAS Institute Inc.

Schmit, J. M., 1964. Thesis, Lyon.

Van der Zijpp, A. J. and F. R. Leenstra, 1980. Genetic analysis of the humoral immune response of White Leghorn chickens. Poult. Sci., 59: 1363-1369.

Wiebe, D. A. and J. T., Bernert, 1984. Clin. Chem. 30: 352.

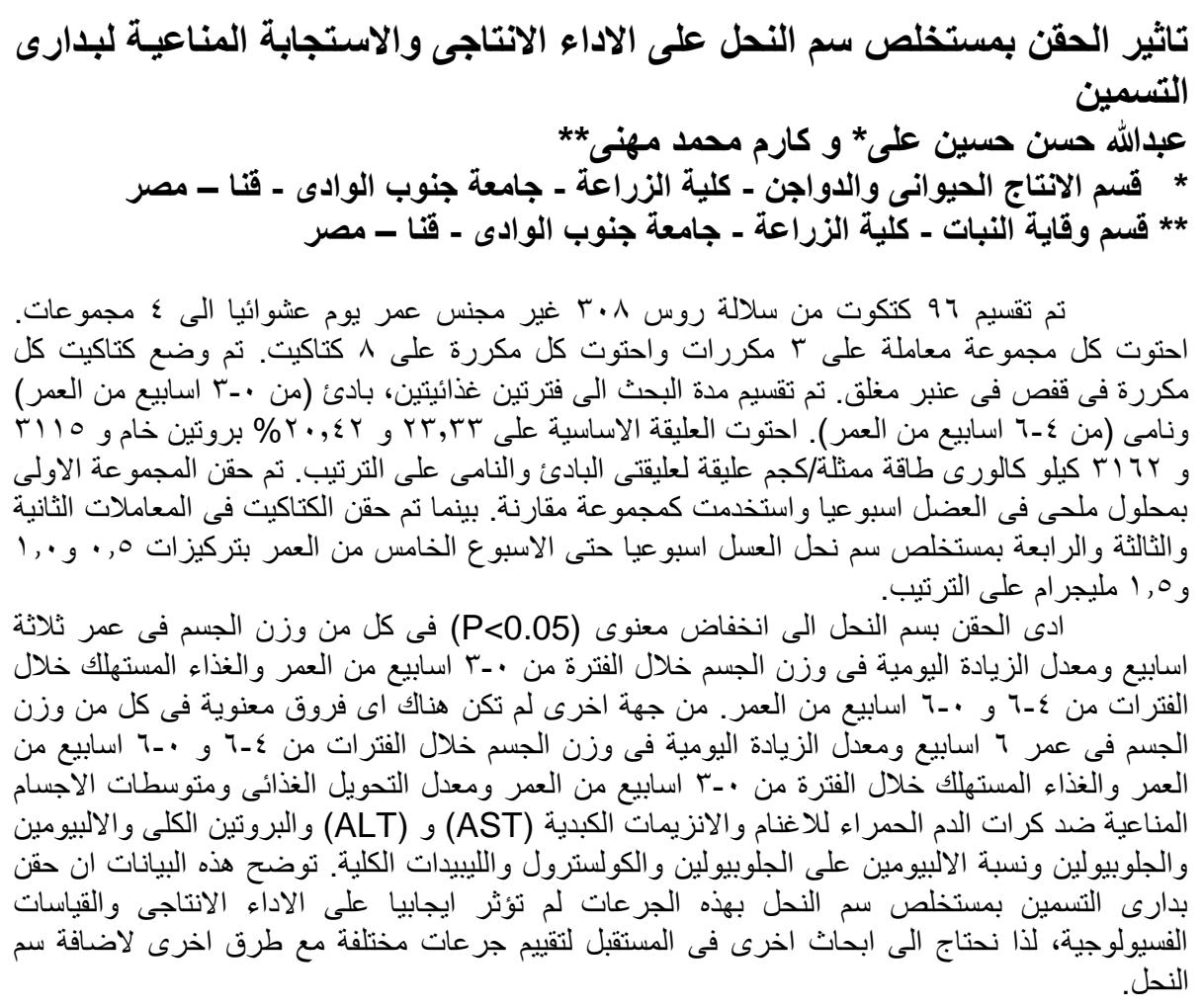

